Urban Governance and Finance in India

M. Govinda Rao and Richard M. Bird

Working Paper No. 2010-68

April 2010

National Institute of Public Finance and Policy New Delhi

http://www.nipfp.org.in 


\title{
Urban Governance and Finance in India
}

\author{
M. Govinda Rao* \\ and \\ Richard M. Bird*
}

\begin{abstract}
Over 330 million people live in India's cities; 35 cities have a population of over a million and three (Mumbai, Delhi, and Kolkata) of the 10 largest metropolises in the world are in India. India's cities are large, economically important, and growing. However, neither urban infrastructure nor the level of urban public services is adequate for current needs, let alone to meet growing demands. Dealing with this problem is a formidable challenge. Not only must adequate finance for the provision of services be found but it is critical to ensure that the money spent results in desired outputs and outcomes. To do so, local governance structures also need to be reformed and strengthened. This paper attempts to point the way towards some possible solutions by analysing urban governance and finance in India in the context of lessons drawn from fiscal federalism theory and experiences of governance institutions and financing systems both in India and around the world.

No one system of urban governance is likely to work equally well for all urban local bodies. However, the paper identifies some key reforms required to realise both the constitutional intent to encourage citizen participation in urban governance and the economic and politically desirable goal of ensuring greater accountability of urban governments. For example, the paper draws attention to existing ambiguities in the assignment system and underlines the need to undertake activity mapping to ensure clarity as well as to make independent agencies significantly accountable to elected governments in urban areas.
\end{abstract}

\footnotetext{
Director, National Institute of Public Finance and Policy, New Delhi, Email: mgr@nipfp.org.in;mgr@vsnl.com

Professor Emeritus of Economics, University of Toronto, Toronto, Canada
} 
The paper also discusses a variety of ways of augmenting the resources of the municipal bodies in the country including essential reforms in the property tax system and adequate exploitation of user charges and fees for various services delivered as well as ways of strengthening and improving Central and State transfers to urban local governments. With respect to financing urban infrastructure, development charges should be used more effectively. More should also be done to utilise public lands more effectively. In addition, to a considerable extent capital expenditure requirements will have to be financed through borrowing so further cevelopment of the municipal bond market is important, as is more and more effective use of public private partnerships in some areas.

JEL Codes: R51, H70

Keywords: India, urban public finance, urban governance, intergovernmental fiscal relations, property tax, metropolitan areas, infrastructure finance 


\section{Urban Governance and Finance in India}

\section{Cities as Centres of Economic Dynamism: Role of Governance and Finance}

Urbanisation and development are inseparably linked in part because cities are the leading edge of economic dynamism in every country. The concentration of enterprises and people from various walks of life in cities facilitates productive interaction and the exchange of ideas and creates a climate for creative activity and enterprise development that leads to innovation and productivity. Cities generate externalities that facilitate transactions, production, and distribution activities and serve as centres of entrepot trade. Large cities in particular may achieve the critical mass required to attain high degrees of specialisation in labour, knowledge and businesses, services, infrastructure, institutions and media, all of which increase economic dynamism (Bird and Slack, 2007).

However, the extent to which cities succeed in realising their potential to galvanise innovation and accelerate growth depends to a considerable extent on whether they succeed in providing not only adequate urban public services but also good policies, high-quality institutions, and the tolerant and open social environment needed to facilitate creative social and economic interaction. Achieving agglomeration economies in cities requires the sustained provision of a wide range of urban public services that underpin both private sector activities and the well-being of the urban population such as water, sewers, garbage collection and disposal, drainage systems, police and fire protection, and transportation. In a world where international economic competition is linked to dynamic urban centres, cities that wish to attract the 'knowledge workers' who are increasingly the drivers of growth also need policies to accommodate diverse cultures (including outsiders) as well as such 'quality of life' factors as high quality schools and healthcare facilities, social and cultural activities, recreational opportunities, and safe and strong neighbourhoods. Moreover, cities must also accommodate all those who make the city work, including new migrants and others who work in construction and other essential activities and often need affordable housing and in many cases some social assistance. Finally, underlying all this, a 'good' city also needs a political and governance system that responds to the requirements and needs of its people swiftly without entailing heavy transaction costs.

Good policies, good local governance systems, and sound arrangements to finance public services are critical elements in sustainable urban development and shape the nature and quality of public services provided as well as the structure of incentives and accountability. Open multicultural policies support cosmopolitanism and attract both capital and labour; in contrast, restrictive policies create insecurity and prevent efficient migration. Cities, to be competitive, need both to provide quality public services in adequate quantities and to be responsive to the requirements of people and businesses. To do so, they not only require adequate sources of finance but also effective participatory mechanisms that elicit the preferences of people and provide the services that meet these preferences. The governance system should also foster accountability by ensuring that, by and large, urban residents themselves pay for the public services 
they receive (except to the extent that urban services provide significant external benefits outside the urban area itself).

In India, over 330 million people live in urban areas distributed over 5,165 cities. Urban population has grown at an annual rate of 2.7 per cent and, even though overall population growth is expected to decelerate, the urban population is likely to continue to grow at about 2.5 per cent until 2031 (Ramanathan and Dasgupta, 2009). In 2005, there were 96 municipal corporations, 1494 municipalities and 2092 Nagar Panchayats in 2005 (India, 2004). Over a million people lived in each of 35 cities, and of the 10 largest metropolises in the world, three (Mumbai, Delhi and Kolkata) are in India. The urban sector presently contributes about two-thirds of GDP and this share is likely to increase to 75 per cent by 2021 (ndia, 2008). India's cities are thus already large, economically important, and growing. Ensuring that they can meet the challenges they face will not be easy.

Demands for better infrastructure and better public services in India's urbanised areas are large and growing. In contrast, the resources now available to urban local governments are clearly inadequate, falling short even of the norms (adjusted for inflation) set long ago by the Zakaria Committee (India, 1963). Mohanty et al (2007), for example, found that on average for the period 1999-2000 to 2003-04 actual spending in 30 large municipal corporations in India was only about 24 per cent of the requirements established by the Zakaria Committee almost half a century earlier. While there was considerable variability in the sample, the extent of 'under spending' on urban services was over 75 per cent in 17 municipal corporations, and indeed over 50 per cent in all of them except for three -- Pune (31.6 per cent), Nagpur (30.8 per cent), and Nasik (35.5 per cent). At the other extreme, spending in the Patna Municipal Corporation was estimated to be only 5.6 per cent of the normative requirement, and the shortfall was over 90 per cent in almost all municipal corporations in the poorest States of Uttar Pradesh and Bihar.

Financing urban infrastructure and services adequately is thus a formidable challenge. The infrastructure deficit in urban areas is not only large but growing. Recent analysis by the Planning Commission shows that 34 per cent of urban households do not have water taps within their premises, 26 per cent of them do not have toilets, 70 per cent of waste is not treated before disposal, and untreated sewerage and unregulated discharge from industries is a major source of water pollution. In total, according to the draft Eleventh Five Year Plan document, only 63 per cent of the urban population had access to sewerage and sanitation facilities in 2004 . Urban transportation problems are similarly acute. Public transportation is congested and inefficient, and even those who can afford private transportation on average travel only a kilometer in 15 minutes owing to road congestion. Housing too is problematic, with almost 21 per cent of the urban population living in squatter settlements.

Such problems are likely to worsen in the near future with continued urban growth. As both, education and skill levels of the population and manufacturing and service sectors expand, migration to urban areas will continue, resulting in a continued high urban population growth rate even as the fertility rate in urban areas declines. Ramanathan and Dasgupta (2009) estimate cumulative capital investment requirements for providing services at 2007 prices for the period 2006-2031 at Rs. 71,251 billion and O\&M requirements at Rs. 10,031 billion. This works out to an annual average of Rs. 
3,251 billion or about 25 per cent of the consolidated revenue receipts of the Centre and States.

Exponentially growing urban public service requirements cannot be financed from local tax bases that are inflexible and have low buoyancy. The only important tax handle urban local governments have is the property tax. At one time, some states allowed urban local bodies to levy a tax on the entry of goods into a local area for consumption, use or sale (octroi). This tax was distortionary and inefficient, but it also provided a buoyant source of local revenues. Now, however, all States except Maharashtra have abolished this tax, and even in the latter, the tax is levied only by municipal corporations and not by smaller municipalities. Some States, like Punjab, Haryana and Rajasthan, have done even more to ensure that urban local revenues are inadequate by abolishing the residential property tax. Everywhere urban local bodies have proved unable (or unwilling) to effect periodic revision of property values, thus rendering the tax non-buoyant in raising revenues. As for other revenue sources, intergovernmental transfers from the States to local governments are not only inadequate, they are also generally ad hoc and poorly designed and targeted. Finally, the absence of a debt market for local government bonds makes financing infrastructure even more difficult.

Turning India's cities into 'engines of growth' is thus a formidable challenge. Not only must adequate finance for the provision of services be found but it is critical to ensure that the money spent results in desired outputs and outcomes. To do this, local governance structures also need to be reformed and strengthened. The aim of this brief paper is to contribute to this task by analysing urban governance and finance in India in the context of lessons drawn from fiscal federalism theory and experiences of governance institutions and financing systems around the world.

The paper is organised as follows. To begin with, section 2 sets out some important preconditions for efficient governance systems and finance drawn from the theory of fiscal federalism. Section 3 then summarises briefly four alternative models of governance to see what lessons international experience in governing large cities might suggests for improving urban governance in India. Section 4 underlines the problems that arise for urban areas in India as a result of ambiguity and overlap in the expenditure assignment system. A key principle emerging from the literature surveyed in section 2 is the importance of ensuring that the cost of providing public services is borne by the residents who benefit from them. Section 5 therefore considers taxes on residents and user charges as an important way to finance local public services while ensuring efficiency and accountability. However, some urban agglomerations may simply not have sufficiently large tax bases to finance the required levels of services from such sources. In such cases, this fiscal disability may have to be offset through transfers from higher level governments. Similarly, if benefits of public services spill across jurisdictions, intergovernmental transfers may again be required. Section 6 discusses such transfers. Local taxes and current transfers together may at best perhaps be able to finance current service provision (including maintenance). As discussed in section 7, however, large urban capital infrastructure such as, roads or water and sewerage systems almost always requires alternative finance through such sources as local borrowing, development charges, land sales, or public-private partnerships. Section 8 concludes.

Financing public expenditures in cities is a key issue in urban planning and development. Since every city is different, no single approach will suit all. The 
appropriate strategy for any city will differ depending upon a variety of factors such as its size, economic conditions, the composition of various population groups within the city, and the extent of urbanisation. Nonetheless, this examination of Indian reality in the context of both theory and international experience with local governance and finance suggests, we think, some clear directions for possible reforms to increase the dynamism of India's cities and realise more fully their potential as engines of national growth.

\section{Fiscal Federalism Theory: Lessons for Urban Governance and Finance}

The theory of fiscal federalism deals with efficiency, equity, and accountability in public service delivery. The traditional theory of fiscal federalism demonstrates the welfare gains from fiscal decentralisation by matching public service provision with the varied preferences of the people living in different jurisdictions. In one formulation, people 'vote with their feet' by moving to localities providing public service- tax mixes that closely matches their preferences (Tiebout, 1956). However, the unrealism of the 'footloose mobility' assumption as well as information asymmetry relating to public services and tax mix in different localities limits the applicability of this model to real world situations. An alternative formulation is the 'decentralisation theorem' which states that "... in the absence of cost savings from the centralised provision of a (local public) good and of inter-jurisdictional externalities, the level of welfare will always be at least as high (and typically higher) if Pareto-efficient levels of consumption are provided in each jurisdiction than if any single, uniform level of consumption is maintained across all jurisdictions" (Oates, 1972, p. 54). The welfare gains from decentralisation are larger when variations in demand are greater and where the demand for local services is relatively inelastic. Although uniform provision of public services need not necessarily result from centralisation per se, the ability of a centralised system to cater to diverse preferences is limited by information asymmetry and political constraints (Oates, 1999).

Traditional fiscal federalism theory assumes that governments are benevolent in the sense that their sole policy objective is to maximise social welfare. In contrast, the "second generation" theory (SGT) of fiscal federalism assumes that agents within governments (bureaucrats and politicians) attempt to maximise their own welfare functions within a constellation of incentives and constraints shaped by the characteristics of the prevailing fiscal and political institutions (Oates, 2008).

One SGT approach applies industrial organisation theories to fiscal federalism and analyses multilevel fiscal arrangements in terms of the principal-agent framework (Seabright, 1996). A second approach, motivated partly by the fiscal crisis precipitated in several Latin American countries as exploitation of "fiscal commons" resulted in perverse behaviour by subnational governments, applies the 'soft budget constraint' developed by Kornai (1986) in the context of State enterprises in socialist economies (Rodden et. al., 2003). A third SGT approach employs more formal political economy approaches based, for example, on legislative structure and electoral process to analyse different kinds of fiscal outcomes under centralised and decentralised politics. As an example, the outcomes emerging from so-called "yardstick competition" are analysed under the rubric of "competitive federalism" by Breton (1996). These approaches are not intended to 
replace the traditional theory of fiscal federalism; rather, they are to be considered as complements to and extensions of that theory.

In principle, theories of fiscal federalism cover all multilevel fiscal systems, irrespective of whether a country is formally federal or unitary, the number of layers in the system, the sizes and capacities of jurisdictions and whether the local governments are in rural or in urban areas. In practice, however, many of the 'lessons' such theories suggest are not easy to apply in a real-world context such as India. For example, since the benefit span of each public service (policing, water supply, street lighting) is different, it is seldom possible to have a different local government that coincides with the benefit span of each public service. Aggregating diverse public services under particular local governments is likely to result both in scale diseconomies and spillovers and efficiency concerns. Similarly, it is seldom appropriate to consider the challenges faced by all subnational governments to be identical when the nature of public services provided, the technology for providing the services, the nature and quality of institutions and their capacities, the bargaining strength needed to resolve spillovers, and the instruments and the capacity to finance the public services may all differ vastly in different cases. Nonetheless, a few general lessons emerge from the literature.

For instance, an important precondition for efficient provision of public services is clarity in the assignment of functions (expenditure responsibilities) to each level of government. Who does what should depend upon the benefit span of the public service in question, the extent of diversity in demand for the service, the technology available for its efficient provision and the capacity of the jurisdiction to provide the service. An important reason for assigning functions clearly not just to jurisdictions but to particular functionaries within each jurisdiction is to ensure responsiveness and accountability. In a democratic polity the elected executive should have the overall decision making powers for public service provision and the role of the bureaucracy is to implement the decisions taken by the executive. Finally, even when the basic assignment system is clear, since some overlapping is almost inevitable, it is also important to establish clear systems and institutions within which to resolve such issues.

Once functions have been assigned according to comparative advantage, financial powers should follow. In assigning local revenue sources, however, it is important to strengthen rather than weaken local accountability. Accountability of governments to local residents can best be achieved when the residents of the jurisdiction bear the cost of providing the services at least at the margin. Hence, bcal governments must have powers to raise revenues so that they can increase expenditures on public services as desired by the residents. Ensuring that there is what Breton (1996) calls a strong 'Wicksellian' linkage between revenue and expenditure decisions at the margin is critical to ensure that urban governments both take rational decisions and are accountable for their decisions.

Local governments generally provide a mix of 'private' and 'public' goods. In principle, user charges paid by those who benefit directly should cover the cost of the private goods provided. Similarly, the cost of public services benefiting the jurisdiction as a whole should be collected from taxes on the residents. On the other hand, services whose benefits spill over the jurisdiction should be partly paid for by taxing residents (equivalent to the benefits received by them) and partly through transfers, as discussed below. Local governments may obviously levy taxes on immobile bases such as real property. In addition, however, the benefit principle suggests that they may also to a 
limited extent be permitted to impose taxes on mobile bases, although such powers must be bestowed with care to avoid encouraging shifting the cost of local services to nonresidents (Bird and Smart, 2009).

Intergovernmental transfers play an important role in fiscal federalism. In the traditional approach, since higher level governments have a comparative advantage in carrying out redistributive and stabilisation functions, they should levy all broad-based redistributive taxes. On the other hand, for efficiency reasons considerable expenditure responsibility is properly assigned to lower level governments. The resulting vertical imbalance between expenditures and revenues at each level is generally corrected through transfers from the higher to lower levels. Within each level of subnational government, some jurisdictions will inevitably suffer some fiscal disability owing to factors such as below average revenue capacity and higher unit costs of providing public services. Differences in these factors create different net fiscal benefits in different jurisdictions and may thus induce inefficient factor movements (Buchanan, 1950). This problem may be exacerbated when subnational governments impose origin-based taxes (Boadway and Flatters, 1982). The solution to such inefficiencies is again usually considered to lie in appropriate intergovernmental fiscal transfers. All such 'balancerestoring' transfers intended to enable every jurisdiction to provide comparable levels of services at comparable tax rates should be unconditional (Bird and Smart, 2002). In addition, however, there is also often a case for providing specific purpose transfers to ensure minimum standards of public services with significant inter-jurisdictional externalities. In this case, the appropriate transfer design is rather different, as discussed further in section 6 below.

In practice, it is invariably difficult to resolve the various issues that arise in designing a system of transfers. There is, for example, no completely objective way to measure the degree of vertical or horizontal imbalance. Similarly, with respect to specific purpose transfers, as a rule it is impossible to measure the degree of externalities and hence to develop optimal cost sharing arrangements or matching ratios. As mentioned above, to some extent the economic argument for decentralisation is based on asymmetric information in terms of the inability of the central government to estimate the correct degree of spillovers, so it is somewhat ironic that the proper design of specific purpose transfers requires exactly such information. As a U.S. study showed (Inman, 2003) in actual practice matching ratios never correspond to the extent of spillovers and the federal share is invariably much higher than the spillovers involved. Finally, even if all the conceptual and empirical problems inherent in designing an economically optimal transfer system could be overcome, invariably non-economic (including political) objectives creep in and ensure that the actual transfer system differs from the ideal.

Moreover, some have even questioned whether intergovernmental transfers are a good idea in any case. Transfers inevitably soften the budget constraint and have been argued to undermine fiscal discipline and promote fiscal irresponsibility and macroeconomic instability (Prud'homme, 1995). Equalising transfers given to offset fiscal disadvantages can interfere with the normal process of income convergence which occurs in the process of economic growth due to the migration of labour and capital from places with lower productivity to those with higher productivity. Specific purpose transfers may also not effectively encourage local expenditures on the desired function owing to the fungibility of funds. For these and other reasons, some have cast serious doubts on the efficacy of intergovernmental transfers in serving the long-term interests of a federation. 
Nonetheless, in reality substantial transfers are found in every federal country between Centre and States and in almost every country between Central and State (or just State) governments and local governments. The reason is essentially simply because perfectly matching revenue powers with expenditure responsibilities is not possible. What does the fiscal federalism literature tell us about how the inevitable transfer system should be designed and implemented? First, if the basic economic case for decentralisation is accepted at all, then the role of transfers should neither be so large as to turn local governments into simple agents of higher level governments or to make them 'transfer dependent' and hence fiscally irresponsible, nor so small as to render them incapable of providing minimal local services to their residents. Second, one key way to strike this 'hard budget constraint' balance is to ensure that richer local governments are as 'self-financing' as possible and that even the poorest local governments have sufficient revenue flexibility so that revenue and expenditure decisions are matched at the margin in the sense that any local decision to expand expenditure must be financed through additional local taxation (Bird and Vaillancourt, 1998). Third, Central and State governments must be careful not to 'bail out' bad local decisions by expanding transfers, which means, in effect, that the system of grants must be transparent, predictable, and essentially 'infra-marginal' for any particular budgetary period so that local governments do not have incentives to free-ride.

For urban dynamism to be fully realised, the national economic space needs to be unified in a common market. Market impediments can arise by restricting the movement of labour, capital and commodities as well as through such institutional factors as linguistic barriers and the lack of a secure environment. In addition, the literature on 'market-preserving federalism' shows that to ensure an efficient nation-wide market, local governments must face a hard budget constraint (Weingast, 1995, 2009). A hard budget constraint is critical to make subnational governments adopt rational and efficient decisions. To reach this point, however, not only must expenditure functions and revenue sources, including transfers, be assigned, designed and implemented properly, but efforts must also be undertaken to strengthen and deepen markets, particularly land and capital markets. Removal of impediments to mobility and trade in factors and products, including the abolition of laws restricting markets as well as removal of institutional rigidities, is an essential ingredient of national and international market success. Efficient credit and debt markets and a well developed banking system along with credible credit rating institutions are important preconditions to avoid bailouts. Similarly, well developed land and property markets and free mobility of factors and products may prevent public sector decisions that impede the development of markets and competition and discourage protectionist policies at subnational levels. Intergovernmental competition can sometimes be beneficial. It may lead to gains in terms of efficient service delivery as well as innovation and productivity gains. To reap such gains, however, it is important to ensure that there is a measure of competitive equality and proper checks against predatory competition as well as against restrictive and protectionist policies. All these issues become particularly important in the context of globalisation because localities with better linkage with markets and infrastructure can reap higher benefits from access to domestic and international markets and grow faster than those with less access to markets and infrastructure. Finally, in case something goes badly wrong in some locality, it is also essential to develop institutions that can handle local 'fiscal crises' and even bankruptcy. 


\title{
III. Models of Urban Governance and Governance Systems in India
}

\author{
(i) Models of Governance:
}

As the theories of fiscal federalism reviewed in the previous section demonstrate, to be economically dynamic, cities need the right governmental structure. The decentralisation theorem, like the 'subsidiarity principle' included in the European Union Treaty of 1992, suggests that efficiency and accountability in public service provision requires decision making by the level of government closest to the citizens. At the same time, economies of scale and minimising coordination costs in providing such services often require a larger governmental jurisdiction, as does efficient raising of revenue. Resolving these conflicting considerations requires the choice of appropriate governance structure which is discussed in this section.

Good governance systems elicit preferences for public services, ensure responsiveness in the provision of such services, provide accessibility to citizens and achieve cost savings by adopting an appropriate scale of operation. Thus, an efficient governance system depends on a variety of actors. In smaller municipalities, all regulatory, planning, revenue raising, and spending decisions will be done by the municipality and the governance system, is simple. However, in larger municipal corporations it is necessary to set up systems to ensure accessibility, responsiveness and coordination. In metropolitan regions, governance systems are even more important. Bird and Slack (2007) discuss four alternative models of metropolitan governance: (i) one-tier model; (ii) two-tier model; (iii) voluntary co-operation, and (iv) special purpose districts. ${ }^{1}$

In the one-tier model, which is common in the United States, a single level of local government is responsible for providing all local services. Most American cities organised in this way are highly fragmented. For example, the Chicago Metropolitan Area has 464 local governments (counties, municipalities, townships) and in Houston, Texas, the central city is surrounded by 790 governments and overlapping special districts. One-tier models are also found in other countries, such as Caracas (Venezuela) and Bogota (Colombia) and Shanghai (China), although in most cases such cities are 'consolidated' one-tier structures. In Shanghai, for instance, although there is essentially a one-tier government, within that tier there are three levels of management - municipal, district, and sub-district. In India, Mumbai has been characterised as a "fragmented onetier structure" (Slack, 2007, p. 15). Mumbai itself has 7 wards, each with its own municipal officials, and the surrounding eastern and western suburbs are also divided into wards. Within the Mumbai urban agglomeration, however, in addition to the municipal corporations of Mumbai, Kalyan, and New Mumbai, there is the Mumbai Regional Development Authority, 16 municipal towns, 7 non-municipal urban areas, and 995 villages. Moreover, management of urban services in Mumbai is divided among the Municipal Corporation of Greater Mumbai, the State of Maharashtra, and the Government of India. For example, the urban rail network is run by Indian Railways.

A one-tier consolidated government may be created by amalgamation of two or more lower tier municipalities or by annexation of areas under adjacent local bodies. All taxing and spending decisions are made at one level. The services delivered in a one-

\footnotetext{
${ }^{1}$ An expanded version of this paper, together with a number of related papers on metropolitan governance, may be found in Rojas et. al. (2008).
} 
tier structure need not necessarily be uniform: for example, if there are dfferences in service levels before amalgamation, they may persist. In the long term, however, there will be pressure towards having uniform services. One rationale for having a consolidated one-tier metropolitan body is that its larger taxable capacity gives it more ability to borrow and levy user charges to cover capital and operating costs of providing services. It is also often argued that amalgamation into a one-tier municipal structure helps to internalise externalities, enables greater economies of scale, helps to achieve better service coordination, ensures clearer accountability, streamlines decision making and enables greater efficiency in service provision (Bahl and Linn, 1992). These arguments played a large role in the adoption of the one-tier model in Toronto (Canada) in 1998. However, experience in Toronto and elsewhere shows that amalgamations do not necessarily result in cost savings. There may be some cost savings as duplication in activities is eliminated, but the pressure to equalise salaries and benefits as well as to raise service levels up to the highest levels prevailing in the new larger municipality may often outweigh any cost savings (Bird and Slack, 2007). An additional advantage of a one-tier governance structure is that it may make it easier to achieve redistributional goals within the metropolitan area. This consideration understandably played a major role in South Africa's decision to introduce one-tier metropolitan governments to replace the former racially-segregated municipalities. However, the one-tier model carries with it the disadvantage of making local government more remote from citizens, thus reducing accessibility. Moreover, amalgamating municipalities may reduce competition and reduce efficiency.

In the two-tier model, the lower tier is responsible for providing services having smaller geographical spread while the upper tier encompassing a larger geographical area provides services with corresponding geographical spread as well as those involving significant economies of scale. This model has some characteristics that make it suitable for large metropolitan regions. Examples may be found, for instance, in Madrid (Spain), Santiago (Chile), and Manila (Philippines), and the two-tier model was adopted in London (U.K.) in 2002. Two-tier structures already exist in many Indian cities. For example, Hyderabad Municipal Corporation has 11 municipalities, Chennai Municipal Corporation has 36 municipalities, and Kolkata has 41 municipalities within its area (Bandyopadhyay and Rao, 2009). In principle, the two-tier model may have potential advantages over the one-tier model owing to its greater responsiveness, efficiency and accountability. Some redistribution is also possible in this structure through a combination of tax and spending decisions. On the other hand, there may also be overlap and duplication in the provision of services. Moreover, since the structure is less transparent residents may be confused as to who is actually responsible for which services.

The third approach to governing metropolitan regions is the voluntary cooperation model, which essentially consists of an area-wide body based on voluntary cooperation among different municipalities with no permanent institutional structure. Examples of such arrangements may be found in Bologna (Italy), Marseilles (France), Vancouver (Canada), and Sao Paulo (Brazil). A variant of this approach focused on solid-waste and waste-water infrastructure development exists in Yogyakarta (Indonesia). Such systems usually develop incrementally as a way to provide services across regions efficiently without requiring formal amalgamation. Individual municipalities retain their identities and remain accessible to residents while at the same time becoming a part of the regional group to achieve economies of scale and scope and coordinate public service delivery. Voluntary cooperation can take the form of inter-municipal agreements - formal or informal -- for the provision of specified services, generally with the objective 
of reducing the costs of providing the service. This approach may be useful for individual services (e.g. regional transit). However, as a general model of metropolitan governance, voluntary co-operation models may not work well or be sustainable over time because the objective functions of the policymakers in different metropolitan regions likely differ. Further, there may be problems of clarity in public accountability, and if things do not go well, inter-municipal conflicts and litigation may erupt.

The fourth governance model for public service delivery in large metropolitan areas is the setting up of specialised agencies. Specialised agencies can provide similar municipal services to several municipalities while minimising unit costs and ensuring efficiency in service provision. In the United States, where such specialised agencies are particularly important, one third of all local governments are school districts (Bird and Slack, 2007). In India, specialised agencies for providing water supply, waste management, and transportation across a number of municipalities already exist. This approach has a number of clear advantages. For example, specialised agencies can reap economies of scale and address the issue of spillovers, can be professionally managed to ensure efficiency and can to at least some extent establish and collect user charges without political considerations. On the other hand, there are also disadvantages to this approach. There may, for instance, be problems of coordination when a number of specialised agencies providing different services are involved. In addition, these agencies may have no local political accountability unless their decisions are subject to the approval by the municipal executive. Furthermore, if municipal taxes go to support such agencies but there is no clear linkage between the expenditure decisions of the specialised agencies and the taxes collected by the municipalities; the absence of the 'Wicksellian connection' between revenues and expenditures further reduces accountability. While specialised agencies can certainly improve efficiency in the delivery of some services, if they are not locally accountable it is far from clear that they are supplying the right services in the right places.

In the end, no unique model of governance can fit all municipalities or even the same municipality at different times. As Slack (2007) notes, for example, in recent years a number of major cities have changed their governance model. Toronto moved from a fragmented one-tier structure to a two-tier structure and then, most recently a consolidated single-tier structure. On the other hand, London moved from a two-tier structure to a one-tier structure and then, most recently, back to a two-tier structure. Cape Town (South Africa) moved within a very few years from having no metro government at all to first a two-tier and then a consolidated one-tier metropolitan structure while over more or less the same period Abidjan (Côte d'Ivoire) moved from one-tier to two-tier to one-tier. What is 'right' for any city is seldom clear, and may change over time. In larger metropolitan areas, however, the real choice boils down to one-tier or two-tier governance structures perhaps supplemented by some voluntary inter-municipal cooperative agreements or specialised agencies to provide particular public services. The most critical point is that there must be some kind of unified system to address regionwide problems and to provide and coordinate public service provision such as transportation, economic competition, social cohesion, and environmental coordination. In addition, to foster and ensure citizen involvement and government responsiveness to local residents, a lower level of local government is often also desirable. Voluntary intermunicipal agreements may sometimes be necessary in some areas to internalise externalities. Similarly, sometimes it may be desirable to create specialised agencies to provide certain regional services although it is important that such agencies should be significantly accountable to local residents. 
The issue of governance in large metropolitan cities must be distinguished from the case of smaller municipalities. In large metropolitan cities, the concentration of a variety of economic activities, the cosmopolitan composition of population, and large migration requires a system of public service provision that not only facilitates economic activities but also promotes the social interaction and cohesion necessary to facilitate innovation and impart dynamism. However, especially when large metropolitan cities are also State capitals, how they are actually governed may deviate substantially from this mandate in response to the compulsions of local politics. Restrictive protectionist policies responding to pressures to provide employment to local population, preferences for local population in business dealings and contracts, and preferences based on linguistic, ethnic, and other considerations may rob cities of their metropolitan character. A possible way to free large cities from such State political pressures may be to remove them from the control of the State governments and create new separate city-states - for example, for cities with a population of more than ten million. Germany, for example, has three such city-states, including Berlin. Brussels is also a separate city-state in Belgium. Berlin and Brussels are of course also national capitals, and many other countries - the United States, Australia, Mexico, and Brazil, for example, have created special capital districts, as of course has India. ${ }^{2}$ In addition to Beijing, China has three metropolitan provinces - Shanghai, Tianjin and, most recently, Chongqing. As Indian experience with the special case of New Delhi shows, however, being special and separate is only at most a partial answer to the financial and governance problems facing large, rapidly growing cities in India (Mathur, 2009), so we do not pursue this possibility further in the present paper.

Until the $74^{\text {th }}$ Constitutional Amendment, the structure of urban governance in India essentially evolved from the compulsions of urbanisation. In principle, the primary responsibilities are vested in the executive Mayor chosen by the elected representatives, and local officials are charged with implementing the decisions taken by the executive. In practice, however, the role of the Mayor (or Chairperson) of the municipality who is the executive head is often confused with that of the Municipal Commissioner - an official who is supposed to implement the policies approved by the Executive. In addition, governance in smaller municipalities often suffers from inadequate administrative capacity to plan, effectively regulate, raise revenues and implement spending decisions. Moreover, both State and Central politicians, in varying degrees in different regions, often interfere in the functioning of municipalities.

Effective fiscal decentralisation requires that not only must appropriate functions and adequate finances be devolved to the local governments, but also control over those they employ. In fact, however, municipal governments do not have the power to appoint their chief official - the Municipal Commissioner, who is instead a State government official deputed by the State government. Since the local government has no role whatsoever in the appointment, promotion, or transfer of the Municipal Commissioner, it is hardly surprising that he is in reality primarily accountable to the State government rather than to elected local representatives. Recently, the Expert Committee on the Governance in Bangalore Metropolitan Region recommended that the Commissioner of Bruhat Bangalore Mahanagara Palike (BBMP) -- the Greater Bangalore Municipal

${ }^{2}$ For a recent detailed study of finance and governance in capital cities in a number of federal States, including India, see Slack and Chattopadhyay (2009). 
Corporation -- should be selected by a high-powered search committee constituted by the State in consultation with the Mayor and, more importantly, that the Commissioner's role should be redefined in the legislation to make him/her clearly responsible and accountable to the Mayor and the corporation. If India's larger cities are to have effective urban governance structures, similar steps need to be taken by all State governments to make the Commissioners in municipal corporations and municipalities primarily responsible and accountable to the respective municipal bodies. Of course, so long as the Commissioner's career path remains essentially in the State bureaucracy, some problem of 'dual subordination' still remains, but at a minimum it is critical that the chief municipal officer should clearly be primarily accountable to the municipality he or she serves rather than to the State, as is now the case.

The constitution places "Local government, that is to say, the constitution and powers of municipal corporations, improvement trusts, district boards, mining settlement authorities and other local authorities for the purpose of local selfgovernment or village administration" as item 5 of the State list in its Seventh Schedule. Urban governance structures are thus determined by the States. Although the $74^{\text {th }}$ Amendment accorded constitutional recognition to the municipal bodies, by and large local governance structures have carried over from the past. To strengthen participatory planning, he constitutional amendment provided for the setting up of Metropolitan Planning Committees (Article 243ZE) to prepare the draft development plan in every metropolitan area. Similarly, District Planning Committees (DPC) were established by Article 243ZD to consolidate and co-ordinate planning coordinated by district panchayats for rural areas and municipalities for the urban areas. The constitutional amendment also mandated the holding of ward sabhas (assembly) to elicit the preferences of the people for public services and to develop planning from the grassroots level. However, none of these requirements were really observed in practice until the Planning Commission mandated the setting up of the DPCs based on the recommendations of the Committee on Grassroots Planning (India, 2005). Despite this mandate, the exercise in grassroots planning continues to be in its infancy. In most States, urban local bodies do not as yet have regular ward sabhas. Even in States that do have them, they are not used as a mechanism for urban planning or eliciting the preferences for public services. Similarly, many States are yet to legislate for let alone to create Metropolitan Planning Committees.

Under Article 243S, State governments are required to constitute Ward Committees comprising one or more wards within the territorial jurisdiction of a municipality having a population of more than 300,000 . In addition to the members representing each ward, the composition of the Ward Committee and the manner of selection of the members is required to be specified in the relevant State Municipal Acts. The objective of having Ward Committees is to provide a mechanism to elicit and respond to the preferences as well as complaints of the people of different wards with respect to public services and again, to establish a mechanism for grassroots planning. In reality, however, this provision has as yet hardly been implemented anywhere, and where such committees have been established they almost never undertake their required functions.

The issue of governance in India's major metropolitan areas is extremely important not only for the millions who live there but also for the economic development of the country as a whole. Big cities need not only a sound governance structure but one that works well. To attain this, steps should be taken to implement the 'preferencerevelation' and citizen access structures set out in the constitution. More immediately 
critical, steps should also be taken to set out clearly the roles that different political and bureaucratic actors are supposed to play at the municipal level and then to let them do their jobs unencumbered by interference by politicians at higher levels of government and with primary accountability to those whom they are supposed to serve - local residents.

\section{What Do Urban Local Governments Do?}

\section{(i) Expenditure Assignment}

The traditional theory of fiscal federalism argues that the essential function of local governments is allocative. The potential mobility of economic agents reduces the effectiveness of local governments in carrying out redistribution. Similarly, the openness of local economies means that they can do little in terms of stabilisation (Oates, 1972). The main task of the local governments is thus to provide local goods and services within the area under their jurisdictions. ${ }^{3}$ Some of these services may be essentially private goods if, for example, markets fail for reasons such as information asymmetry or if public policy purposes require such provision. Except when overridden by distributive considerations, efficiency requires that local governments should levy user charges to those who benefit from the private goods -- such as water supply, sewerage, transportation and recreation services -- that they povide. On the other hand, bcal public services benefiting the local population in general should be financed by taxing residents, while services whose benefits spill over jurisdictional boundaries usually need to be financed in part by intergovernmental transfers. Finally, in principle the best way to finance large capital investments that will continue to provide services long into the future is through borrowing. Of course, it is important to ensure that neither transfers nor borrowing turn into bailouts that soften the budget constraint facing local government decision-makers.

The $74^{\text {th }}$ Constitutional Amendment, Article 243W, allows the legislature of a State to devolve such powers and functions to its municipalities as needed to enable them as self-government institutions as well as for the "preparation of plans of economic development and social justice" and the performance of functions and implementation of schemes as may be entrusted to them including the 18 functions to be devolved to the municipal bodies listed in the Twelfth Schedule to the constitution.

Some important observations relating to the present functional domain assigned to municipal bodies must be noted. First, the listed items are identical for all types of municipal bodies - the municipal corporations, municipalities and nagar panchayats. Second, since the extent of devolution of functions to the municipal bodies is left to the discretion of the State governments the extent of devolution may vary significantly across municipal bodies in different States. In general, State governments are reluctant to devolve functions to the local governments on the grounds that they do not have the capacity to undertake them. Third, since the 18 listed 'municipal' items are all also either in the State list or in the concurrent list of the Seventh Schedule of the constitution, there

\footnotetext{
${ }^{3}$ This does not mean that local governments do not have any role in redistributive or stabilisation functions. Local governments sometimes have local employment programmes (Inman and Rubinfeld, 1997) and may also play a role in implementing anti-poverty interventions (Rao and Das Gupta, 1995; Rao, 2002).
} 
is considerable concurrency and overlap not only between the State government and municipal bodies but also between the central government and the municipal bodies. It is therefore difficult to assign responsibility for the provision of specific services to a specified level of government, let alone to ensure that those who make the decisions are adequately accountable for their actions. This problem is particularly acute in the capital cities of the States where the overlap in functions between the State government and the municipal corporation makes the system opaque. In Delhi, the overlapping problem is even more acute as all the three levels of government - Centre, the union territory of Delhi and three municipal bodies - the Delhi Municipal Corporation, New Delhi Municipal Committee and Delhi Cantonment divide the powers among hem in confusing ways (Mathur 2009).

There is nothing wrong with concurrent assignment of powers if there is clear demarcation of functional domains. Clarity in assigning property rights is essential to the proper functioning of private markets, and clarity of expenditure assignment is equally essential in ensuring efficiency and accountability in the provision of public services. However, to achieve clarity in functional domains given concurrent assignment requires careful "activity mapping" of functions to municipal, State and Central governments. In the case of rural local governments, the Ministry of Panchayati Raj has helped to undertake activity mapping for district, block and village level panchayats in many States. Although this effort to date is neither complete nor perfect, it has helped to achieve a measure of clarity in the functional domains. However, no States have yet taken the initiative to undertake the activity mapping for municipal governments that is necessary to know precisely who is responsible for doing exactly what with sufficient clarity to achieve efficiency and accountability in the provision of urban local services. Moreover, since both the nature of functions and the capacity to undertake them generally differ with the population size of the municipalities, separate activity mapping exercises are needed for municipal corporations, municipalities and town panchayats.

As mentioned above, the Twelfth Schedule lists 18 functional areas for the urban local governments, leaving it to the State governments to specify the domains of the urban local governments in these areas. What most State governments have done is to formalise the functions that were being carried at by the municipal bodies even before the constitutional amendment. Municipalities across the country have been vested with a long list of functions by the State governments under their respective municipal legislations relating to public health, welfare, safety, regulation and developmental activities. Functions relating to public health include water supply, sewers, sanitation, and waste disposal/management. Welfare activities include social justice, safeguarding the interests of weaker sections, creation and running of night shelters, street lighting, parks, education, burial grounds and cremation facilities, playgrounds and recreation. Regulatory functions include prescribing and enforcing city plans, landuse and building by-laws, licensing of shops and establishments, removal of encroachments on public land, registration of births and deaths, enforcing parking regulations and Public safety includes fire protection and street lighting. Public works includes construction and maintenance of inner city roads and buildings. Development functions include town planning and development of markets.

In addition to all these core functions, the $74^{\text {th }}$ Constitutional Amendment specifically assigned a number of additional development functions to municipal governments in the Twelfth Schedule including planning for development, urban poverty alleviation, protection of environment and slum improvement and upgrading. In most 
States, the various functions have been divided into obligatory and discretionary functions although the division between the two categories is not uniform. In principle, although municipal governments may have a comparative advantage in implementing many aspects of the functions listed in the Twelfth Schedule, there are also many other functions that might be implemented by them equally well but that are not included in the schedule. In this sense, it might perhaps be said that the assignment system does not follow the principle of subsidiarity. However, there is nothing to prevent States from assigning additional (unlisted) functions to municipal bodies if they are found to have a comparative advantage in undertaking them.

Although the functions listed in the Twelfth Schedule do not make any distinction between municipal corporations, municipalities and nagar panchayats, the scope and capacity to undertake various functions is in fact likely to vary with, inter alia, the size and character of the municipal body. The assignments actually made by State governments are supposed to take such factors into account. For example, in many States the large municipal corporations have been assigned significant powers with respect to education and healthcare, the regulation of industries, and the provision of intra-city and inter-city transportation services. Interestingly, provision of transportation services is not one of the functions listed in the Twelfth Schedule. Nor is electricity distribution, although some municipal corporations undertake this task through such departmental enterprises as the Bombay Electricity Supply and Transport (BEST) in Mumbai.

Another complication with respect to expenditure assignments to municipal governments is the emergence in some areas of independent service providers to provide some public services, bypassing the elected municipal governments. This is precisely a result of disenchantment with poor public service delivery by municipal bodies. Independent service providers are also often thought to insulate policy making from political vagaries and hence to enable the professionalisation of policy and implementation in regard to public service delivery. In some cases, such providers deliver services beyond boundaries of one municipality, adopting improved technology to reap economies of scale in service provision. The most important example is the creation of separate water supply and sewerage bodies in the States to provide services across several municipalities. The main problem that may arise with this type of organisational set up is the agency's relative remoteness from the people it serves and its lack of political accountability. In drawing up agreements with such service providers, careful attention must be paid to balancing the desire for professional competence and least-cost provision against the need for local governments to be fully accountable to their residents for the provision of the public services for which they pay.

\section{(ii) Public Financial Management}

Even if activity mapping leads to the establishment of clear lines of responsibility and accountability, clarity of assignment in terms of specifying exactly what services each government is responsible for delivering is only part of the story. Clarity must be matched both by accountability in terms of democratic accountability to the local population and by authority in terms of the ability to manage expenditures and to determine (within limits) revenues. Both financial honesty and political accountability require that municipal budgeting, financial reporting, and auditing should be not only comprehensive, comprehensible, comparable, verifiable, but also transparently public. In Brazil, for example, and increasingly in other countries, more and more local budgets and financial accounts are freely accessible on the internet, and in some instances residents 
are actively encouraged to participate to some extent in developing the expenditure plans for their areas.

Whether one goes this far or not, proper public expenditure management at any level of government must (a) adequately control the total level of revenue and expenditure; (b) appropriately allocate public resources among sectors and programmes; and (c) ensure that governmental institutions operate as efficiently as possible. To do this, urban local governments need adequate authority to manage both the expenditure and revenue sides of their budgets, sufficient administrative capacity to be able to do so, and an appropriate incentive structure to encourage them to do so. Most Indian cities are handicapped in all these areas. As discussed below, properly structuring local taxes and intergovernmental transfers as well as fostering a sound local borrowing market will go a long way towards establishing the hard budget constraint needed to ensure that local decision-makers respond to the right incentives and tend to allocate the funds available to them efficiently and effectively. In addition, however, both central and State governments need to provide a more adequate fiscal, financial, and institutional framework for urban local government to bring to reality the intentions of the $74^{\text {th }}$ Constitutional Amendment. They also need to ensure that local officials are adequately trained and motivated to do their jobs properly. A strong central hand may often be needed to ensure that good rules are in place, and are complied with. For example, Central and State governments might establish a model 'framework' local budget law and financial reporting system and require adequate external audit. Improving the local budgeting and financial system along these lines will satisfy two essential requirements of good government. First, it will establish the basis for financial control. Second, it will provide reasonably accurate, uniform, and timely financial information.

Improving local finance information is not a small matter. Improved accountability may be the key to improved public sector performance, but improved information is the key to accountability. The systematic collection, analysis, and reporting of information that can be used to verify compliance with goals and to assist future decisions is critical to successful urban development. Such information is essential both to informed local participation through the political process and to the monitoring of local activity by the central agencies responsible for supervising and (sometimes) financing such activity. Unless local 'publics' are aware of what is done, how well it is done, how much it costs, and who paid for it, no local constituency for effective government can be created. Similarly, unless central agencies can monitor and evaluate local performance, there can be no assurance that functions of national importance will be adequately performed once they have been decentralised. An important underpinning and accompaniment of any successful programme to strengthen urban local bodies must therefore be, perhaps paradoxically, an improvement in national evaluation capacity. Decentralisation and improved central evaluation and assessment of local activities are not substitutes; they are complements.

One essential element of the hard budget constraint needed to induce efficient decisions by local governments is adequate Central (and State) capacity in the shape of credible information-gathering and evaluation. Such 'carrots' of central financial support of local efforts as the JnNURM programme discussed below need, at least implicitly, to be accompanied by the possible 'stick' of reduced support if performance is inadequate, and in order to wave a credible stick, one needs some standard of adequacy and some way of knowing how performance measures up. Decentralising a function to local governments thus does not imply that the Central and State governments no longer have 
any responsibility. Rather, it means that the nature of central responsibility has changed to regulating and monitoring the efficiency and equity of services delivered by local governments. The essential tool needed for this task is an adequate and up-to-date information base -- generated, for example, by requiring local governments to file uniform and informative budgets and financial and other reports. Unfortunately, this need for extended and reliable information on local public finances and service delivery to date has been sadly neglected in India.

Two final points might be mentioned related to the issues just discussed. First, while some financial oversight of local finances by State and even Central officials is clearly necessary - not least because to a considerable extent local governments are spending State and Central funds - devising and implementing a system of oversight that balances prudence with leaving the main decision-making powers at the local level is not a simple task. Both conceptually and empirically, even in countries with excellent data, it has proven difficult to develop ways of measuring local fnancial performance that will provide adequate indications of possible local mismanagement and, more importantly, impending financial distress. It is important that much more effort and thought be put into developing and implementing a municipal financial reporting system that will be much more adequate in this regard than the present 'non-system.' Second, if municipal governments are given more scope for making their own decisions on what to do, some will undoubtedly make mistakes and in some instances perhaps even 'bankrupt' a locality. While some such errors are undoubtedly an essential part of 'growing' a more adequate urban governance and finance structure, it is important that how such mistakes should be dealt with is considered carefully as part of the needed rethinking of how India's big cities can and should be run more effectively and efficiently. Under what circumstances if at all, for example, should municipal governments be taken over by States? When a municipality cannot pay its debts or meet its current payroll, should it be 'rescued' by a State agency and placed in 'trusteeship' until its financial position is again sustainable? Such questions are not easy to answer in general anywhere, but they must nonetheless be thought given careful.

\section{Financing Urban Services: User Charges and Local Taxation}

As emphasised earlier, an important rule of sound fiscal decentralisation is that finances should follow functions (Bahl, 2002). Local governments need access to adequate revenue sources to finance the public services they are mandated to provide. In India, however, under funding of municipal services is a common feature. Although all States have devolved the municipal functions listed in the Twelfth Schedule to a greater or a lesser degree, in the absence of adequate resources, municipal bodies have not been able to provide satisfactory levels of the assigned public services. One reason is simply because the revenue handles assigned to them to carry out these functions are clearly inadequate. At the same time, however, until now municipal bodies have neither taken the task of delivering public services sufficiently serious nor made adequate efforts to mobilise revenues efficiently from the sources assigned to them. Similarly, there are also not yet in place properly designed systems of intergovernmental transfers to sufficiently offset the fiscal disabilities of the municipal bodies to ensure minimum standards of important municipal services. In total, the net result of assigning the 
constitutionally mandated functions to municipal bodies has thus been to impose unfunded mandates on them, as we discuss further in the next section.

The consequence is that municipal services in India are significantly underfunded as mentioned in section 1 above. The serious under-spending documented by Mohanty et al (2007) has resulted in such inadequate infrastructure and poor public service delivery by municipal bodies that it has seriously constrained the potential role of cities as centres of economic growth (India, 1996; Ramanathan and Dasgupta, 2009; Bandypodhyay and Rao, 2009). In 2005, the poor state of urban infrastructure and services was a major motivation for initiating a central programme, the Jawaharlal Nehru National Urban Renewal Mission (JnNURM) with the objective of improving developmental incentives by linking grants for urban renewal to reforms at both State and local levels aimed at improving fiscal efficiency of the urban local bodies, freeing urban land and housing markets, and preventing the municipal bodies and the States from adopting protectionist policies. The first phase of the programme is for the period 200512. Although in the first two years the progress was slow, the resource transfer from the centre has picked up. Nevertheless, much more remains to be done to augment urban infrastructure and services. Furthermore, the global financial crisis and the slowdown in the Indian economy as a consequence have recently led the central government to dilute the reform requirements in order to provide more immediate fiscal stimulus. In particular, a considerable portion of hNURM funds have recently been spent in purchasing buses for urban transport in order to revive the commercial automobile sector as a component of fiscal stimulus strategy. Despite such shortcomings, as discussed further in the next section, the JnNURM approach may both foster urban renewal and motivate the States and local governments to undertake some of the reforms needed to generate significant own resources through the reform of property taxes and the liberalisation of land and housing markets.

As mentioned earlier, according to the principles of fiscal federalism, local services, by and large, should be paid for, by local residents. User charges are appropriate for financing locally provided services of a 'private good' nature. Local public goods should be financed through local taxes, and the cost of financing services whose benefits spillover jurisdictions should be shared through specific purpose transfers. Additional transfers from higher levels of government are required to offset the fiscal disabilities of jurisdictions with low revenue raising capacity and higher unit cost of providing services in order to enable comparable levels of public services at comparable tax rates. Finally, large local capital expenditures producing a stream of benefits flowing over a number of years should be financed through borrowing or perhaps the proceeds from selling land or other assets belonging to the local government.

As with expenditures, revenue sources, capacities and patterns may differ vastly not only between different classes of municipal bodies but also within each class. Although the expenditure needs of large metropolitan governments are large, for example, so are their capacities to raise revenues. To ensure that local decision-makers face hard budget constraints, it is important to avoid transfer dependency and bailouts. To ensure efficiency and accountability, it is important that there is a strong linkage between the expenditures incurred on behalf of local residents and the payments by way of user charges and taxes those residents make.

Statutorily, local governments in India cannot run deficits; they are required to restrict their expenditures to available revenues. However, the absence of deficits in the 
municipal bodies does not mean that the standards of public services are provided by them are even close to adequate. As Mohanty et. al (2007) recently showed, for example, on average 30 large municipal corporations with more than one million population according to Census 2001 were spending less than that one-quarter of the amount needed to provide the (inflation-adjusted) service norms set out almost 50 years ago by the Zakaria Committee (India, 1963). Municipal spending is so low both because of problems in mobilising own revenues and the inadequacy of transfers from central and State governments. Unfortunately, reliable data on municipal finances are not available; for example, the data reported in the Finance Commission reports have several infirmities (Rao and Rao, 2007). According to the information contained in the Twelfth Finance Commission Report, in 2001-02 the aggregate revenues of urban local bodies as a ratio of GDP amounted to an abysmal 0.67 per cent while their own revenues were only 0.38 per cent. Information collected at NIPFP for the same year shows aggregate revenues marginally higher at 0.76 per cent of GDP, with 0.26 per cent from tax devolution transfers and grants, and the balance from own revenues of urban local bodies at 0.51 per cent (Mohanty et. al, 2007), of which local taxation accounted for 0.38 per cent and user charges 0.13 per cent. (India, 2007). Such figures are very low in comparison with countries like Brazil, where municipal revenues account for 7.4 per cent of GDP, municipal own revenues for 2.58 per cent, and municipal taxes for 1.95 per cent (Afonso and Araujo, 2006). It is unsurprising that the standards of municipal services in India are abysmal.

\section{(i) User Charges}

In many respects, the most important source of finance at local levels should be from user charges imposed for services provided. To a considerable extent a local government is like a business providing direct services in the form of 'private goods' (like water) to its customers -- local residents. Financing such services through user fees or charges not only provides funds with which to supply such services but also provides invaluable information on which services should be provided, in what quantity and quality, and to whom. Given the proximity to the population and the predominance of private good characteristics of many local services, levying user charges is feasible. Often, however, it is complained that it is not possible to levy user charges when the quality of the services rendered is poor. The result is that a vicious circle is set up, with low quality public services leading to an inability to collect user charges leading to further deterioration in the service levels.

This circle needs to be broken, not only to get more revenues but also to improve standards of principal services. User charges are especially important as for providing signals to consumers of the scarcity value of the services and to providers about the demands that need to be met through service provision. Establishing this strong link between demand and supply both helps to generate resources and ensures efficiency in production and accountability in service delivery. User charges are particularly relevant for services such as water, sewers, electricity, garbage disposal, public transit, and recreation. User charges are more important in large metropolitan areas. Marginal cost pricing will improve efficiency by imposing higher charges on far away consumers. However, if poorer people live further away and congestion is serious in metropolitan centres, it may sometimes be argued that it might be advisable to charge more uniform (average cost) prices throughout the urban region for certain services even at the price of perpetuating (and encouraging) some continued inefficiency in urban land use, transportation patterns, and the allocation of urban public sector resources. Of course, 
this is very much a 'second-best' approach, and depends very much upon the physical and social characteristics of each city. Marginal cost pricing of the 'disservice' provided by congestion (as discussed later) combined with marginal cost pricing of other services would clearly be preferable but seems unlikely to be feasible soon in most large Indian cities.

At present, urban fees are not significant in India, with the proceeds from non-tax revenues from all urban local bodies amounting to a mere 0.13 per cent of GDP. Mohanty et. al (2007) show that in 10 large municipal corporations less than 10 per cent of the cost of providing services was recovered through fees; in another six, cost recovery was between 10 to 20 per cent. Only in two of the 25 municipal corporations examined was cost recovery greater than 75 per cent. Interestingly, on the whole cost recovery was relatively greater in those cities in which the estimated normative underspending was lower. If low cost recovery and poor service quality are thus connected, it may prove possible to collect more user charges, especially if the quality of the services provided can be improved - for example, by well-directed transfer payments, as discussed in a later section.

Other important sources of non-tax revenues are licence fees for shops and establishments and parking fees. A common feature seen virtually in every urban local body, particularly in large corporations is the poor implementation of regulations relating to land use and commercial space occupation. Both the present system of issuing licences and the common flouting of regulations by shops and establishments provide enormous rent seeking opportunities. Public interest litigation relating to the construction and running of businesses in residential areas against the regulations led to the demolition of several shops and establishments in Delhi in 2005. In some cities, from time to time, the poor implementation of the regulations has been accompanied by periodic amnesties that legalise them after the fact, favouring in particular the politically well connected and powerful. For instance, recently the State government of Karnataka attempted to pass an ordinance regularising 7000,000 illegal constructions within the Bangalore Municipal Corporation area on the eve of an election to the municipal body. The scheme (called the Akrama-Sakrama Scheme) was approved by the State cabinet but in the end did not receive the approval of the Governor on the grounds that the government should pass the legislation and not simply pass an ordinance.

Finally, revenue from parking fees in major metropolitan cities œuld generate substantial revenues. The main rationales for levying parking fees are to reduce congestion of vehicles on the roads and to generate resources to construct parking spaces. At first glance, these two objectives may seem contradictory since increasing parking spaces in itself might seem more likely to induce rather than reduce road congestion. However, in most metropolitan cities in India, the combination of the poor quality of public transportation system, inadequate provision of parking spaces for vehicles and the present negligible charges for parking either legally or illegally, results in large scale traffic congestion on roads. With sharp increases in household incomes and the emergence of a large middle class, the number of vehicles is going to increase sharply in the coming years. Introducing as part of a more rational road and urban policy a more comprehensive policy of charging parking fees in accordance with the scarcity value of open spaces in cities should both reduce traffic and at the same time generate revenues to construct multi-storeyed parking places. Creating better parking infrastructure in the central business district of major metropolitan cities may be an 
appropriate area in which to explore the public-private partnership approach to capital finance discussed in the next section.

\section{Local Taxation}

Reliable and effective local taxation is essential to ensure hard-budget constraints in financing local public goods (Oates, 2005). In particular, it is important that local governments have adequate tax powers to ensure a strong linkage between revenue and expenditure decision at the margin (Bird and Smart, 2009).

Which taxes are best suited at local levels? On the whole, the fiscal federalism literature suggests that not only should governments (at all levels) bear clear public responsibility at the margin for financing expenditures for which they are politically responsible but that, ideally, local own-source revenues should be sufficient to enable at least the richest local government to finance from its own resources at least those services that they provide which primarily benefit their residents. Indeed, to avoid distorting the allocation of resources, to the extent possible local taxes should burden only local residents, preferably in relation to the benefits they receive from the services provided. For this reason, in general immobile tax bases are best suited at the local level because taxes on mobile bases may result in their migration from higher to lower taxed localities and even result in a "race to the bottom". However, in many cases, particularly in larger cities, taxing immobile bases alone will not yield the revenues required to provide local public goods and services, some of which benefit mobile factors. Indeed, as Oates (1999, p. 1125) says,"... on efficiency grounds decentralised governments should tax mobile economic units with benefit levies." Determining an appropriate tax structure for local governments thus requires a careful compromise between fiscal autonomy and tax efficiency.

A local tax designed to satisfy these requirements should in principle have the following characteristics (Bird 2006):

- The base should be relatively immobile to allow the local authorities to vary the rates without losing the base.

- The tax should yield adequate revenues to meet local needs and should be sufficiently buoyant overtime.

- The tax should be stable and predictable overtime.

- It should not be possible to export the tax burden to non-residents except to the extent that such burdens capture benefits non-residents obtain from local services.

- The tax base should be visible to ensure accountability.

- The taxpayers should perceive the tax to be reasonably fair.

- The tax should be relatively easy to administer.

Based on the above considerations, Bird and Slack (2007) review the various possible candidates for local taxes. The most appropriate tax at the local level is clearly the tax on real properties not only because real property is immobile but also because to a considerable extent differences in service levels are reflected in property values so that the tax on real property is like a benefit tax. In addition, income taxes generate significant revenues for local governments in many OECD countries, and a good case can be made for a supplemental local income tax to supplement property taxes 
particularly in metropolitan areas in which local governments provide substantial services to people (health, welfare) that are not significantly capitalised into property values; in effect, the local income tax might serve as a kind of (very rough) benefit tax with respect to such services. The best way to levy an income tax at the local level is to 'piggyback' it on higher level income taxes so that, although some flexibility with respect to the tax rate can be given to local governments, the determination of the base and tax administration will remain at the higher level. A local payroll tax may be easier to administer but it is generally not a good idea since it acts as a tax barrier to employment and may reduce the employment intensity of production. Another tax often used at the local level is some form of sales or consumption tax, including selective taxes on (for example) entertainment services and hotels. Finally, a number of countries have local business taxes that take such forms as corporate income tax, differentially heavy non-residential property tax, transit taxes such as octroi and entry tax, and various forms of gross receipts and crude sales or 'industry and commerce' taxes (Bird, 2003). Most of these local business taxes involve significant exportation of tax burden to non-residents, are costly to administer, and impose substantial compliance burdens.

In India, municipal bodies can levy and collect only those taxes that are specified by the State governments from the State List in the Seventh Schedule to the constitution. Although the taxing powers assigned are non-uniform across States, on the whole the most important tax bases assigned to municipal governments include (i) taxes on lands and buildings (49), the tax on the entry of goods into a local area for consumption, use or sale which is known as octroi (52), (iii) taxes on luxuries including those on entertainment, amusement, betting and gambling (55), (iv) taxes on advertisements other than advertisements published in newspapers, or broadcast in radio or television (55), (v) taxes on non-motorised vehicles (57), (vi) taxes on animals and boats, (vii) tolls, and (viii) taxes on professions, trades, callings and employment.

In actual practice, however, most of these taxes are simply not levied. The most important tax actually levied at the local level is undoubtedly that on land and buildings (real properties). Octroi was an important source of municipal revenue in some States until recently, but as the tax was considered obnoxious, distorting, iniquitous, and a major source of corruption, it is not surprising that all States except Maharashtra have abolished the tax and even in Maharashtra, the tax is levied only in municipal corporations. Some States replaced octroi with entry tax which is not much better in economic terms and is also an impediment to internal trade. In most cases, even when the States replaced octroi by entry tax, they did not compensate municipal governments for the loss of revenue. Generally, when States abolished octroi, they provided no alternative source of revenue and simply increased the size of the unfunded mandates confronting municipal governments. In a few States, however, municipal governments have some access to consumption taxes. In Kerala, for instance, the power to levy entertainment tax is given to the urban local governments. In Andhra Pradesh, local governments receive a fixed share of the revenue from entertainment tax. In a few States, urban local bodies collect some revenue from advertisement tax.

Although the property tax is the most important source of own revenues of municipal bodies, it suffers from several infirmities as evidenced by the generally poor collections and low buoyancy of this tax. However, initiatives in some municipal corporations in recent years have shown that revenues from this tax can be substantially increased with proper reform of the tax system. Bruhat Bangalore Nahanagara Palike 
(Greater Bangalore Municipal Corporation), for example, reformed its property tax by revising the area-based values, introducing a self-assessment system and improving the technology of the payments system with the result that revenue increased from Rs. 4,400 million in 2007-08 to Rs. 7,800 million in 2008-09 and is expected to further increase to Rs. 10,000 million in $2009-10$.

The starting point for property tax reform in India was the introduction of areabased assessment to determine the tax base by the Patna Municipal Corporation in 1992-93. Previously, the tax was collected on the basis of the annual rental value, defined as gross annual value rent at which the property may 'reasonably' be expected to be rented out. This system gave enormous discretion to the tax collectors and yielded little in tax revenue. The prescription of unit values (per square foot) based on the area of location and type of construction of the property instead of the annual rental value removed most of the discretion from the tax collectors and resulted in such a large increase in base that the tax rate was reduced from 44 per cent to 9 per cent. ${ }^{4}$ Subsequently, municipal corporations in a number of States adopted the Patna model. In Bangalore, for example, properties are classified into different zones based on the guidance values set by the Department of Stamps and Registration. For each zone, rental value per square foot was determined on the basis of type and quality of construction and age of the buildings. A handbook was brought out detailing the above so that each individual property owner would compute his tax liability simply by plugging in the location, type of construction and sq. feet area of his property, and then pay the tax online. Similar reforms in other urban local bodies might also double their revenues from property tax.

A major weakness of this system, however, is the need to revise the unit values periodically in keeping with changes $\mathrm{n}$ prices. In the absence of periodic revision, revenues will not respond to changes in the values of properties, and the buoyancy of the tax will depend only upon the addition of new properties. As a rule, it is politically difficult to change the values periodically. One way to overcome this problem might be to link the guided values automatically to the index of property values in various cities determined by the National Housing Bank. This system could be expanded if States would initiate the estimation of price changes on real property in every urban local body based on the methodology adopted by the National Housing Bank and then link the guided values automatically to the price index to estimate the tax liability.

Some important lessons from the Bangalore experiment in the reform of property tax must be noted. First, the system should be simple and transparent enough to be easily understood by the general public. Second, there should be clarity in the reform process with thorough public discussion and debate when the reform is adopted. It is important for the tax department to provide prompt and clear answers to queries by the general public in newspapers, videos, and audio channels. It is also important to facilitate online payment of the tax so that the taxpayer does not have to be in contact with the tax collector. Computation of the property tax liability based on the guided values and online payment of the tax obviates the need for taxpayers to go to the tax department and face harassment simply in order to pay the tax.

\footnotetext{
${ }^{4}$ In view of the very considerable degree of under-spending in Patna - the worse of the 30 cities examined by Mohanty et al (2007) -- its pioneering role in property tax reform has apparently not been carried through over time in a way that sustains municipal revenues.
} 
Another major reform needed in the property tax system is the expansion of the tax base. The Administrative Reforms Commission has noted that only about 60-70 per cent of the properties in urban areas are actually assessed. A large number of property owners seem to be simply not paying the tax although they benefit from the local public services. The Commission recommended the matching of the properties paying the tax with those in the Geographical Information System (GIS) to identify those that are not paying the tax. In fact, BBMP has undertaken has undertaken this exercise for all properties within its 800 sq. kilometre area. By matching the actual properties paying the tax, excluding government buildings and slums, it is possible to identify the properties evading the tax. The Bangalore reform experiment is worth emulating in other municipal corporations and municipalities.

One reason for widespread evasion is because much new construction as well as additions to existing buildings have been done without getting proper approval. Some have expressed the fear that allowing such properties to pay the tax could mean giving them legal recognition. It is important to keep these two issues separate. It is also important to examine the nature of violations. In general, if violations are not major, property owners should be allowed to pay the penalty and regularise them. On the other hand, in cases where the violations are major, the structures should be demolished.

Apart from the property tax, which is potentially a good source of local revenues but definitely needs to be reformed substantially, larger cities in particular are likely to need some additional broad-based tax source, such as a supplemental rate 'piggybacked' on a national or State tax and administered with that tax, but with the proceeds going to the local government. Any such local rates should be set within predetermined limits. A ceiling is needed to prevent localities from 'exporting' tax burdens (in excess of benefits received) to non-residents and a floor to prevent richer areas from 'stealing' tax base from poorer areas.

In India, at present the centre can levy income tax only on non-agricultural incomes. The power to levy the tax on agricultural income is vested with the States and the latter have not levied the tax except on income from the plantation sector. Ideally, this distinction between sources of income should be done away with to have comprehensive income as the tax base while making adequate provision for insuring fluctuations in agricultural incomes and allowing carry over losses. If and when such a tax exists, and is operating relatively well on a comprehensive income base determined by the Centre, presumably both State and even some larger local governments might be allowed to piggyback their rates subject to a ceiling rate. Such a system would reduce the scope for evasion and avoidance of income tax, provide a stable source of revenue to both State and local governments and in particular provide large business and manufacturing centres like Mumbai with funds to maintain and upgrade their infrastructure to sustain their key role in India's national economic dynamism. However, before such measures can be considered many changes would have to take place not only at the constitutional level but also, equally importantly, in terms of political willingness to tax adequately and properly at all levels of government. Finally, major efforts would also be required to ensure that the central income tax system was functioning properly before it was further complicated by adding on such sub-national components.

Of more immediate interest is the possibility that a surcharge on the consumption tax might perhaps be an important additional source of revenue for the municipal 
governments. The consensus is that there will be a dual GST - one at the Centre and another at the State level. By and large there will be uniformity in the tax base and rates. As the economy is gearing up to move over to the goods and services tax (GST) at both Central and State levels, it would in principle be feasible to levy a small surcharge on the State GST. In fact, even in the prevailing State VAT, Gujarat decided to impose an additional one percentage point levy on the sales tax and earmark the levy for compensating the municipal corporations for the loss of revenue by abolishing octroi. As the present consumption tax system is replaced by the GST regime, the possibility of providing some additional revenue to local governments by (as in Japan, for example) levying an additional percentage point for this purpose at either the central level or perhaps as each state decides at the State level, and then distributing the revenues to localities by formula might perhaps be considered. Conceivably, some States may perhaps even want to consider allowing at least the large metropolitan areas to 'piggyback' an additional rate of their own on the State tax base but this is unlikely to be a good idea given the complexities involved in making such a system work ${ }^{5}$ Firm estimates of GST base are not available but a conservative estimate made at NIPFP for 2007-08 put the GST base at Rs. 16,000 billion after adjusting for the prevailing exemptions (Rao and Chakraborty, 2010). A one per cent levy on this base would yield Rs. 160 billion for municipal governments which is about 0.34 per cent of GDP. Since even the most optimistic estimate of revenue from property tax is just about 0.2 per cent of GDP (Mathur, Thakur and Rajyadhyaksha, 2009), a one per cent levy on the GST could yield virtually double the amount collected from property tax. This possible important source of revenue deserves to be considered seriously in the immediate future.

As a final note on local taxes, it is particularly important that States cease the pernicious practice of abolishing local taxes without providing adequate substitute sources of revenue to municipalities. For example, the Gujarat government abolished octroi to fulfil its election promise without any mechanism to compensate the municipal corporations, although later they decided to levy a one percentage point additional rate on the sales tax. Rajasthan and Haryana simply abolished the property tax without even consulting the urban local governments. Punjab put the threshold for the property tax so high that almost two-thirds of the properties are exempted. Since property tax is the only important tax for municipal governments, when a State government abolishes or severely restricts this tax, it is deliberately disempowering its municipalities.

\section{Financing Urban Services: Intergovernmental Transfers}

In principle, municipal governments should raise revenues to finance local public services from their residents. In reality, however, not only is the assignment of revenue powers generally inadequate but in many cases municipalities do not have tax bases large enough to generate the required revenues. Transfers from higher levels of government either by way of tax devolution or grants are therefore found in every country, as are specific purpose transfers intended to ensure minimum standards of services for those with significant benefit spillovers.

\footnotetext{
${ }^{5}$ Even Canada, which makes considerable use of such provincial 'piggyback' rates on its central GST as described in detail in Bird and Gendron (2009), has not considered, and is unlikely to consider, extending this facility below the level of the province.
} 
In the Indian context, under Article 243 (1) of the constitution, the State governments are required to appoint a State Finance Commission (SFC) every five years to determine:

- the distribution between the State government and the municipalities of the net proceeds of the taxes, duties, tolls, and fees that can be levied by the State which may be divided between them, and the allocation of such proceeds between the municipalities at all levels;

- the determination of the taxes, duties, tolls and fees which may be assigned to, or appropriated by the municipalities;

- the grants-in-aid to the municipalities from the consolidated fund of the state;

- the measures needed to improve the financial position of the municipalities; and

- any other matter referred to the SFC by the Governor in the interest of sound finance of municipalities.

After the $74^{\text {th }}$ Amendment to the constitution, the terms of reference to the Central Finance Commissions (CFC) were amended under Article 280 (3) (cc) to include an additional clause to make recommendations on the "measures needed to augment the Consolidated Fund of the State to supplement the resources of the municipalities in the State on the basis of the recommendations made by the Finance Commission of the State." In fact, however, the CFCs could not make recommendations on the reports of the SFCs in part because there was no coordination of the timing of the submission of the reports of the SFCs with the result that their reports were simply not available to the CFCs. In any case, many SFC reports were simply unusable, either because they were not accepted for implementation by the States or because the methodology employed was not only not uniform but also left much to be desired.

The Twelfth Finance Commission at the Centre reviewed the progress in setting up SFCs as well as their recommendations and concluded that (i) several States did not appoint the SFCs on a regular basis; (ii) in many States the recommendations of the SFC were simply not followed up; and (iii) even when they were accepted by the governments, they were not fully implemented in either letter or spirit and the annual budgetary allocations were often well short of the recommendations. In many cases, the SFCs appointed did not have the expertise to undertake the technical exercises required to estimate the requirements of the municipalities. Furthermore, in most states, the information and data required to undertake technical exercises either do not exist or the SFCs do not have the time or capacity to collect the information required to undertake the task. Not surprisingly, the transfer system to municipalities suffers from several shortcomings in most states and is ad hoc, inadequate, opaque, and often discretionary. The objective of providing an objective and scientific basis for such transfers by appointing SFCs has definitely not been achieved.

Since the CFCs are unable to take account of the recommendations of the SFCs, they simply set some token amount for municipal grants in their recommendations. For instance, the Eleventh Finance Commission recommended a grant of Rs. 20 billion for the five years, 2000-05 and the Twelfth Finance Commission recommended Rs. 50 billion grants to urban local bodies for the period, 2005-10. 
The upshot is that the block transfers given to urban local governments from both the Centre and States are wholly inadequate and bear no relationship to their expenditure needs. The constitution provides for the appointment of State Finance Commissions to determine the requirements of urban local bodies. However, State governments do not take this task seriously when it comes to appointing the Commission or considering their recommendations. SFCs are ill equipped to undertake the difficult task of assessing the revenue potential and expenditure needs of the municipal governments. Not only that most of them do not have the professional capacity to undertake the task, but the information and data required for the purpose are not collected regularly or reliably. The result is that the grants given are not only grossly inadequate but also are ad hoc and usually based on past trends. After transfers, as before, urban local bodies are left with large unfunded mandates and woefully inadequate public services.

Specific Purpose Grants

Most specific purpose grants are given by central government ministries for various central sector and centrally sponsored schemes. The major specific purpose transfer for urban local bodies is under the Jawaharlal Nehru Urban Renewal Mission (JnNURM) in which grants are given to upgrade the urban infrastructure on the condition that the States and the municipalities will undertake reforms. As mentioned earlier, this ambitious programme is designed to augment urban infrastructure and services and is linked to a reform agenda that includes doing away with urban land ceiling act and rent control act as well as reforms in property tax etc. The Government of India proposes to spend about Rs. 500 billion during 2006-12 with matching contributions from cities/States. In Track I, under hNURM, assistance to augment urban infrastructure will be given for 63 identified cities to enable planned development of the cities, ensure integrated development of urban infrastructure and ensure provision of urban services to the poor. Under Track II, assistance under Urban Infrastructure Development Schemes for Small and Medium Towns (UIDSSMT) and Integrated Housing and Slum Development Programmes (IHSDP) will be extended to other cities.

The admissible components for assistance under JnNURM include urban renewal, sewerage and water supply, solid waste management, storm water drainage, urban transport, parking spaces on PPP basis, development of heritage areas, prevention and rehabilitation of soil erosion, and preservation of water bodies. As mentioned earlier, the grants under the scheme are linked to reforms both at the State and at municipal level. Municipal level reforms include introduction of an accrual based accounting system, reform of the property tax by using GIS information, levying user charges to recover 100 per cent of operation and maintenance charges, provision of basic services to urban poor, and internal earmarking of budgets for this purpose. State level reforms under JnNURM include enactment of public disclosure law, full implementation of the provisions of $74^{\text {th }}$ Constitutional Amendment including the setting up of District Planning Committees (DPC) and Metropolitan Planning Committees (MPC), enactment of community participation law, associating elected representatives with the function of city planning, repeal of urban land ceiling act and reform of rent control act, and rationalisation of stamp duty to bring it down to no more than 5 per cent within the next five years. In addition, there are optional reforms relating to revision of bye-laws, simplification of legal and procedural frameworks for conversion of agricultural land for non-agricultural purposes, earmarking 20-25 per cent of developed land for economically weaker sections (EWS) of the population, introduction of computerised process of 
registration of real properties, making water harvesting mandatory in all buildings, and bye-laws to introduce re-cycling of water, encouraging public-private partnerships, and sundry structural and administrative reforms. The grant and loan portions and the matching ratios for the Centre, State and local bodies (including parastatals and financial institutions) are shown in the following table.

\begin{tabular}{lccc}
\multicolumn{2}{c}{ Financing Pattern for JNURM } \\
(Per cent of Total Project Cost)
\end{tabular}

JnNURM is clearly a comprehensive specific purpose scheme for urban renewal and infrastructure support. Indeed, it is if anything too comprehensive and might perhaps have been more effectively focused on a shorter and more easily attainable list of objectives. In any case, not that much has yet happened since states have so far been reluctant to undertake reforms and avail the assistance. In the first year (2005-06) of operation, the revised estimate of grants was just about 15.6 per cent of the budget estimate. In the second year, although the estimate increased to 78 per cent of budget, the total amount disbursed was less than Rs. 36 billion. Since 2008-09, however, actual disbursements have increased sharply. Unfortunately, this increase in part reflects some dilution of reform content and in part the fact that the funds were liberally used to purchase buses in municipal corporation areas as a part of the fiscal stimulus to the commercial vehicles sector. Putting more buses on already overcrowded urban streets is perhaps more likely to increase than to reduce congestion and other ongoing urban management problems. More fundamentally, the reluctance of States to undertake the pro-market reforms called for by JnNURM is a matter for concern.

\section{Financing Urban Infrastructure}

If India's cities are to be centres of dynamism in the country, considerable investment in augmenting urban infrastructure and services is unavoidable. As mentioned above, reforms in user charges, property tax, and the transfer system as well as perhaps additional funding through a 'local' surcharge on the GST can do much to bring about significant improvement in the resources required for basic urban public services and maintenance expenditures. However, substantial improvements in urban infrastructure will require resources well beyond the capacity of even the best run urban local bodies to generate. International experience shows that major capital works in urban areas are often financed at least in part from central funds, and this seems right when some of the benefits from such works may be felt nationally, as well as locally. The major effects of urban infrastructure projects, however, are clearly felt locally and the major benefits are 
reaped, usually through capitalisation in local property values, by local residents (including local businesses as well as households). It thus seems only right that much of the cost should also be substantially borne by local residents. Four ways to finance major capital expenditures are discussed briefly below: local borrowing; levying developmental charges in the residents; selling land and other assets; and public-private partnerships.

\section{(i) Borrowing}

When the benefits from infrastructure projects are enjoyed over a period of time, it may be both fair and efficient to finance such projects in part or whole by borrowing. Moreover, borrowing may be the only practical way to finance large capital projects without large and undesirable fluctuations in local tax rates from year to year. However, municipalities in India can contract loans only if they are permitted to do so by the State government. ${ }^{6}$ In most cases, the State governments have to guarantee local borrowings, in which case the loan becomes the liability of the State and is included in the overall ceiling under the respective fiscal responsibility legislations. States are reluctant to guarantee municipal bonds because their fiscal responsibility legislation requires them to limit their committed liabilities to half a per cent of Gross State Domestic Product (GSDP) and their fiscal deficit at 3 per cent of GSDP. ${ }^{7}$ Municipal corporations must thus issue bonds on the strength of their own credit rating rather than based on State government guarantees.

The State governments permit urban local governments to borrow under their respective municipal laws, which lay down the framework for borrowing: the projects for which the borrowing is allowed, the volume of borrowing and the security to be pledged, the procedure for applying to the State for the permission to borrow, and the manner in which accounts must be kept. If local bodies borrow without State government guarantees, generally they must place some revenue stream in escrow in order to guarantee the service of the debt. In most cases, State governments only allow municipal corporations to borrow from the market-based on the value of their real property tax base. Most States have issued guidelines for local borrowing such as that borrowing should be for less than 30 years, that the interest rate should not exceed interest rate on government securities and that there should be sufficient provisioning for debt servicing.

The practice of municipal corporations accessing funds from the capital market is relatively recent. By and large, most borrowing by municipal corporations has been from public institutions such as Housing and Urban Development Corporation (HUDCO) or Life Insurance Corporation (LIC) for housing and water supply schemes. After the Credit

\footnotetext{
${ }^{6}$ In fact, under Article 293 of the constitution, even State governments have to seek the permission of the central government to borrow if they are indebted to the latter. The pattern of plan financing until 2004-05 necessarily implied that the States are indebted to the Centre since it involved a large proportion of plan assistance given as Central loans to States. Hence when states borrow from the market, in effect the Union Finance Ministry, Planning Commission and the Reserve Bank of India, really determine the allocation of market borrowing to each of the States.

${ }^{7}$ The 3 per cent GSDP target recommended by the Twelfth Finance Commission was supposed to be reached by 2009-10. However, the Government of India raised the fiscal deficit limit to 3.5 per cent and later to 4 per cent of GSDP in 2008-09 as a part of its fiscal stimulus package, and many States have revised their targets accordingly. The Twelfth Finance Commission also recommended that States should enact fiscal responsibility legislation; 28 States, with the exceptions of Sikkim and West Bengal, have done so.
} 
Rating Information Services Ltd (CRISIL) began credit rating municipal corporations in 1996, the groundwork necessary for the municipal bond market was established. Ahmedabad Municipal Corporation was the first municipal entity to issue Rs. 1 billion bond with the credit rating of $A_{+}$. Subsequently, other credit rating agencies also have joined the business of rating municipal corporations and a number of municipal corporations have issued bonds, particularly after the Ministry of Urban Development issued guidelines for tax-free municipal bonds. The critical requirement for issuance of such bonds is that the municipal corporation issuing the bonds is required to maintain a debt-service coverage ratio of at least 1.25 throughout the period. ${ }^{8}$

Despite these developments, not much has happened in the municipal bond market in India. The volume of bonds issued has been very small, and the trading in bonds very thin. In total, only nine municipal corporations have so far issued bonds amounting to Rs. 6.2 billion, in part because few can fulfil the over-collaterisation condition mentioned above. Although so far the amount of resources raised for investment from the bond market by the municipal corporations is small, with the exception of the bonds issued by Bangalore Municipal Corporation and Indore Municipal Corporation, all others were issued on their own strength and not based on State government guarantee. So long as there is no state bailout, as time goes on the demonstration effect may lead to still more municipal recourse to borrowing for capital finance. Furthermore, another impetus for widening and deepening the bond market is that under the hNURM the Centre and States will together provide 50 per cent of the resources required for investment in urban infrastructure as grants, provided the other 50 per cent is generated or borrowed by the municipal corporation.

\section{Development Charges}

One way to finance basic urban infrastructure, particularly in new areas being developed within the areas covered by municipal bodies, is to levy development charges based on the land area being developed. This is a one-time levy imposed on property developers (including development authorities) to finance growth-related capital costs relating to the area where the development takes place. The objective is to finance the infrastructure associated with the new development project by taxing those who are presumed to benefit directly in the form of increased property values as a result of the new infrastructure. Generally, the developers recover the amount by charging the property owners based on the land area owned by them in the new development project. Who ultimately bears the cost of course depends on the demand and supply conditions for land and housing in the area. On the whole, however, in view of the relative scarcity of land and the strong demand for land and houses in urban areas, in most cases presumably development charges are ultimately borne by the buyers. When welldesigned and implemented, development charges in effect amount to a form of marginal cost pricing of urban infrastructure and may thus encourage more orderly and efficient development of urban agglomerations.

As mentioned, development charges are feasible in newly developed areas within urban agglomerations. However, in places where parallel development authorities have been set up to create housing infrastructure, the charges are collected by them and not by the municipal bodies. Unfortunately from the perspective of sensible urban

\footnotetext{
${ }^{8}$ Debt-service coverage ratio is defined as the ratio of net income (after meeting all obligations) to long term debt service obligations.
} 
finance and planning, such authorities are directly responsible to the respective State governments and not to the municipal body concerned. ${ }^{9}$ Dividing up capital and operational functions and finances $\mathrm{n}$ this way may make it more difficult to develop coherent urban policies.

(iii) Proceeds from Sale of Land and Buildings

In all urban areas, given the high growth of urban population, land for housing and for commercial purposes is scarce. In many urban agglomerations, as just mentioned, development authorities have been set up to acquire land and to develop it either for sale or to directly build affordable houses for the poor and middle income groups ${ }^{10}$ They acquire land from private owners, mostly agricultural lands in the surrounding areas, put the basic infrastructure in place, and sell them for housing or commercial building purposes. Generally, they generate considerable surpluses which could be used to improve infrastructure and services in municipal areas.

Despite what was just said about the scarcity of land for housing and commercial purposes in most cities, in fact there is often considerable such land potentially available in urban areas, much of which is owned by public sector agencies such as railways and defence as well as by municipal bodies themselves. An essential first step is to make a complete inventory of land available for development and sale in municipal areas. Once this is done, it may be possible in many cases to develop such lands, sell them, and use the proceeds to finance urban infrastructure. In the case of the defence sector, for example, when cantonments were initially created they were outside cities. However, as cities expanded over the years, they have come within the urban agglomeration. Cantonments run their own systems of service delivery including schools and hospitals and can certainly be located outside the city limits, reducing the risk to the safety of civilians at the same time. The central government, with co-operation from the State governments, should take action to relocate such establishments, with the State government or the municipal corporation paying for he cost of land acquisition and redevelopment. The relocation of defence establishments could release large chunks of land and thus help reduce skyrocketing real estate prices. The proceeds from the sale of these properties can be used for the redevelopment of defence establishments outside the city, and the surplus revenue after meeting the redevelopment cost may be earmarked for augmenting urban infrastructure and services.

Much the same could be done with vacant land belonging to other agencies which could also, after proper development, be disposed of, and the proceeds shared between the municipal body and other owners. When the development of infrastructure by the municipal body increases the capital value of such land, any gains realised through sale should be shared with the municipal body that has increased the urban infrastructure and services in the area. Of course, all these issues are contentious, and consensus on them will not be easy to achieve. Nonetheless, if Centre and State governments can cooperate in doing so, it should certainly be possible to work out a formula for sharing the proceeds from the sale of land.

\footnotetext{
${ }^{9}$ The Delhi Development Authority until recently was not even accountable to the Delhi State administration but was under the Union Home Ministry.

${ }^{10}$ In some instances, the development authority has ended up acting as a monopoly agency, thus restricting the supply of housing in cities and defeating its original purpose.
} 
Getting different components of the public sector to cooperate is sometimes so difficult that many may think a better approach might be to deal with the private sector. Indeed, public-private partnerships (PPPs) may have significant potential for financing and delivery of urban services. For example, the private sector may be asked to contribute funds for specified services in return for certain rights or future incomes. There are many services such as water supply sewerage, solid waste management, recreational facilities, rain water harvesting, and urban transportation where public-private partnerships are eminently feasible, in principle.

Indeed, PPPs have a number of potential advantages in delivering urban public services. First, the urban local government does not have to spend the money upfront. Second, contracting out services may result in greater efficiency as better service delivery. Empirical studies show that contracting out generally results in lowering of unit costs of services (Kitchen, 2002). In India, Chennai was the first city to embark on the initiative to contract out municipal solid waste management services to a foreign private agency- ONYX, a Singapore based company. The scope of privatisation includes activities such as sweeping, collection, storing, transporting of municipal solid waste and creating public awareness in three municipal zones. ONYX collects about 1100 metric tons of waste from three zones per day and transports it to open dumps. This experiment holds a lot of promise for other municipal corporations and municipalities as well. A number of other municipalities have contracted out waste disposal and solid waste management to the private sector including the NGOs.

Another example of successful PPP is in the provision of water supply in HubliDharwar, Belgaum and Gulbarga cities of Karnataka State. Residents of these cities used to get water supply for only one or two hours a day. However, the PPP arrangement, undertaken on a pilot basis to cover about 2 lakh residents in the three cities, enabled them to enjoy the benefits of $24 X 7$ water supply with a state of the art water distribution system and at little additional cost. The private partner in this case is a French water company 'Veolia Water' which was entrusted with the task of providing 100 per cent metered customer connections. The responsibility for providing adequate supply of bulk water was entrusted to the Karnataka Urban Water Supply and Drainage Board (KUWSDB). Considering the enormous success of this pilot, Karnataka government has approved upscaling of the project to the entire population in the three cities (Ahluwalia and Nair, 2010).

Mixed public-private financing of urban infrastructure definitely deserves to be further explored in the Indian context. At the same time, care must be taken to ensure that certain conditions are satisfied if this approach is to produce beneficial results. This approach is most likely to prove successful when projects are carefully designed and implemented, and when the responsible public agencies are technically and financially able to hold up their end of the deal. Weak governments cannot rely on private agents to overcome their weaknesses and expect to make the best possible bargains for the public, they represent. Governments must also be careful that they do not end up assuming the 'downside' risk of projects, while allowing their private partners to reap any 'upside' gains. Smilarly, care must be exerted to ensure that what occurs is not simply the replacement of public sector borrowing by (often more expensive) private sector borrowing. Privatising the design, construction, and operation of urban infrastructure may have many merits if done properly, but it is neither a panacea, nor free. 


\section{Concluding Remarks}

World over, cities are the central drivers of growth: they are the leading edge of economic dynamism. However, the extent to which cities fulfil this role by promoting competition, galvanising innovation and accelerating growth depends critically on the nature and adequacy of urban governance and finance. Adequate finance is necessary to ensure satisfactory standards of infrastructure and services; governance systems determine not only the allocative and technical efficiency of spending but also the responsiveness and accountability with which services are actually delivered. Thus, good policies, efficient and responsive local governance systems and sound arrangements to finance public services are critical elements in sustainable urban development. They shape the nature and quality of public services provided, as well as the structure of incentives and accountability.

This paper attempts to bring out the important issues involved in improving governance systems and ensuring adequate finances to transform Indian cities into centres of economic dynamism. It identifies a number of reform areas in the context of lessons drawn from fiscal federalism theory and experiences with governance institutions and financing systems around the world. Implementation of these reforms is important to ensure competitive standards of urban public services and effective governance systems that are responsive, efficient, and effective.

Clearly, no one system of urban governance is likely to work equally well for all urban local bodies. The governance system adopted should vary with the size of the urban local body and the nature of the institutions in the area where the local body is located. The paper identifies some key reforms required to ensure greater citizen participation in urban governance. It also suggests that one possibility that should be considered is for the largest cities to be accorded independent status similar to the States in part to insulate them from localised and parochial biases. The governance system in cities should promote cosmopolitanism and accommodative policies to promote healthy social and economic interactions.

An important factor that determines efficiency in service delivery is clarity in expenditure assignment. The paper draws attention to existing ambiguities in the assignment system and underlines the need to undertake activity mapping to ensure clarity. Lack of clarity in the assignment system is not only between the states and urban local bodies; there are also confusing areas of concurrence between urban local bodies and independent agencies delivering various services. The introduction of a number of assisted schemes from the Centre and direct transfer of resources to the independent agencies delivering various services has confounded matters further. Clear activity mapping and making independent agencies significantly accountable to elected governments in urban areas is important. Equally important is activating the institutions and mechanisms mandated in the constitution for participatory planning such as District Planning Committees and Metropolitan Planning Committees as well as ensuring the meaningful functioning of Ward Committees.

Financing urban infrastructure and services adequately is a formidable challenge. The infrastructure deficit in urban areas is not only large but growing. In contrast, the resources available to urban local governments are scant. The result is the present poor state of urban infrastructure and significant under-provision of municipal services. Even 
in terms of the norms fixed as long ago as 1963 by the Zakaria Committee, the actual spending in 30 large municipal corporations in India was less than a quarter of their requirements. Financing urban public services, therefore, is a key to imparting dynamism to the cities which is a necessary prerequisite for taking the economy into a double digit growth trajectory.

The paper discusses a variety of ways for augmenting the resources of the municipal bodies in the country including essential reforms in the property tax system and adequate exploitation of user charges and fees for various services delivered. The paper also suggests that consideration should be given to the possibility of empowering metropolitan governments to piggyback on the GST when it comes into existence: even a 1 per cent surcharge on this base could generate one and a half to twice the amount of revenue that is being collected fom the property tax at present. The paper also makes important recommendations for the reform of central and State transfers to urban local governments.

With respect to financing urban infrastructure, development charges should be used more effectively and more should also be done to utilise public lands more effectively. In addition, to a considerable extent capital expenditure requirements will have to be financed through borrowing. Development of the municipal bond market is, therefore, an important area where much remains to be done. Credit rating municipal governments, encouraging them to undertake reforms, and ensuring hard budget constraints are all important for developing a healthy bond market. Another important area is to encourage public private partnerships. The paper points out some successful cases of PPPs which have helped to augment water supply and solid waste management in municipal bodies. It is important to involve the private sector in the provision of urban services to the extent feasible to ensure efficiency and accountability.

Reform of urban governance and finance are critical not only to improving the quality of life of the people living in urban areas but also to ensure that cities, and especially the large metropolitan areas, become the drivers of economic growth in the country. Ensuring adequate availability of finances and improving governance is an imperative, and the rate at which urbanisation is taking place makes it urgent than reform initiatives must be undertaken. If India is to expand its national rate of economic growth significantly, concerted action to reform both urban policies and urban initiatives are required soon. 


\section{References}

Ahluwalia, Isher and Ramesh Nair, 2010. "Yes, We Can Deliver Water 24 X \&", Financial Express, January 27.

Afonso, J.R. and E.A, Araujo, 2006. "Municipal Organization and Finance: Brazil," in (ed.) Shah A., Local Governance in Developing Countries, Washington, DC: The World Bank.

Bahl Roy, 2002. Implementable Rules of Fiscal Decentralization" in (ed.) M. Govinda Rao, Development, Poverty and Fiscal Policy. New Delhi:Oxford University Press. Pp: 253-277.

Bahl Roy, W. and Johannes F. Linn, 1992. Urban Public Finance in Developing Countries. Oxford University Press for The World Bank.

Bandyopadhyay, Simanti and M. Govinda Rao, 2009. Fiscal Health of Selected Indian Cities, Policy Research Working Paper No. 4863, World Bank, Washington DC.

Bird, Richard M. 2003. "A New Look at Local Business Taxes", Tax Notes International, 30; 695-711.

Bird, Richard M. 2006. "Local and Regional Revenues: Realities and Prospects," in (eds.) Bird Richard M. and Francois Vaillancourt, Perspectives on Fiscal Federalism. WBI Learning Resources Series, World Bank, Washington; 177-96.

Bird, Richard M. and Pierre-Pascal Gendron, 2009. The Canadian Example: The GSTHST-QST-RST System. Paper forthcoming in Tax Law Review.

Bird, Richard M. and Enid Slack, 2007. "An Approach to Metropolitan Governance and Finance", Environment and Planning C: Government and Policy, 25; 729-755.

Bird, Richard M. and Michael Smart, 2002. "Intergovernmental Fiscal Transfers: Lessons from International Experience," World Development, 30 (6); 899-912.

Bird, Richard M. and Michael Smart, 2009. "Assigning State Taxes in a Federal Country: The Case of Australia," (Processed).

(Eds.) Bird, Richard M. and Francois Vaillancourt, 1998. Fiscal Decentralization in Developing Countries. Cambridge: Cambridge University Press.

Boadway, R.W. and Frank Flatters, 1982. Equalization in a Federal State: An Economic Analysis. Economic Council of Canada, Ottawa: Canadian Government Publishing Centre.

Breton, Albert 1996. Competitive Governments. Cambridge: Cambridge University Press.

Buchanan, James 1950. "Federalism and Fiscal Equity", American Economic Review, 40(4); 421-32 (September). 
India, 1963. Augmentation of Financial Resources of Urban Local Bodies._Report of the Committee of Ministers, Constituted by the Central Council of Local Self Government (Chairman: Zakaria)

1996. The India Infrastructure Report: Policy Imperative for Growth and Welfare (Chairman: Rakesh Mohan), Ministry of Finance, Government of India, New Delhi.

-------, 2004. Report of the Twelfth Finance Commission, Ministry of Finance, Government of India.

------, 2005. Report of the Committee on Grassroots Planning (Chairman: V. Ramachandran), Ministry of Panchayati Raj, Government of India.

-------, 2008. Eleventh Five Year Plan, Planning Commission, Government of India.

Inman, Robert 2003. "Transfers and Bailouts: Enforcing Local Fiscal Discipline with Lessons from U.S. Federalism" in (eds.) Jonathan Rodden et.al Fiscal Decentralization and the Challenges of Hard Budget Constraints. London: MIT Press.

Inman Robert and David Rubinfeld, 1997. "Rethinking Federalism", Journal of Economic Perspectives, 11; 43-64.

Kitchen H. M. 2002. Issues in Municipal Finance: Spending, Revenues, Governance, and Administration. Toronto: Canadian Tax Foundation.

Kornai, Janos. 1986. "The Soft Budget Constraint”, Kyklos, 39(1); 3-30.

Mathur, Om Prakash, 2009 "New Delhi, India," in (eds.) Enid Slack and Rupak Chattopadhyay, Finance and Governance of Capital Cities in Federal Systems, Published for Forum of Federations by McGill-Queens University Press, Montreal; 126-62.

Mathur, O. P., Debdulal Thakur, and Nilesh Rajadhyaksha, 2009, Urban Property Tax Potential in India, National Institute of Public Finance and Policy, New Delhi.

Mohanty, P. K., B. M. Misra, R. Goyal, P. D. Jeromi, 2007. Municipal Finance in India An Assessment, Study No. 26., Department of Economic Analysis and Policy, Reserve Bank of India, Mumbai.

Oates, Wallace E., 1972. Fiscal Federalism, New York: Harcourt, Brace and Jovanovich. -, 1999. "An Essay on Fiscal Federalism", Journal of Economic Literature, 37; 1120-1149 (September).

-----------, 2005. "Toward a Second Generation Theory of Fiscal Federalism", International Tax and Public Finance, 12; 349-373.

2008. "On the Evolution of Fiscal Federalism: Theory and Institutions", National Tax Journal, 61(2); 313-333. 
Prud'homme, Remy, 1995. The Dangers of Decentralization", World Bank Research Observer, 10; 201-220.

Ramanathan, Ramesh and Shubagato Dasgupta, 2009. Estimates of Urban Infrastructure Financing Requirements in India, 2006-2031 (Processeed)

Rao, M. Govinda and Arindam Das-Gupta, 1995. "Intergovernmental Transfers and Poverty Alleviation", Environment and Planning C: Government and Policy, 13(1); 1-23.

Rao, M. Govinda, 2002. "Poverty Alleviation under Fiscal Decentralization", in (ed.) Rao M. Govinda, Development, Poverty and Fiscal Policy. New Delhi: Oxford University Press.

Rao, M. Govinda and U. A. Vasanth Rao, 2008. "Expanding the Resource Base of Panchayats: Augmenting Own Revenues, Economic and Political Weekly, XLIII (4); 54-61 (January 26).

Rao, Kavita and Pinaki Chakraborty, 2010. "Goods and Services Tax in India: An Assessment of the Tax Base", Economic and Political Weekly, XLV(1); 49-54 (January 2).

(Eds.) Rodden, Jonathan, Gunnar S. Eskeland and Jennie Litvack, 2003. Fiscal Decentralization and Hard Budget Constraints. Cambridge, MA: MIT Press.

(Eds.) Rojas, Eduardo, Juan R. Cuadrado-Roura, and Jose Miguel Fernandez Guell. Governing the Metropolis: Principles and Cases. Washington DC: Inter-American Development Bank.

Slack, Enid, 2007. Managing the Coordination of Service Delivery in Metropolitan Cities: The Role of Metropolitan Governance, Policy Research Working Paper 4317, Washington, DC: The World Bank.

(Eds.) Slack, Enid and Rupak Chattopadhyay, 2009. Finance and Governance of Capital Cities in Federal Systems, Published for Forum of Federations by McGill-Queens University Press, Montreal

Seabright, Paul, 1996. "Accountability and Decentralization in Government: an Incomplete Contracts Model", European Economic Review 40; 61-89.

Tiebout, Charles, M. 1956. "A Pure Theory of Local Expenditures", Journal of Political Economy, 64; 416-24.

Weingast, Barry, 1995. "The Economic Role of Political Institutions: Market Preserving Federalism and Economic Development", Journal of Law and Economic Organization, 11; 1-31 (April).

Weingast, Barry, 2009. "Second Generation Fiscal Federalism: The Implications of Fiscal Incentives", Journal of Urban Economics, 65; 279-293. 